\title{
EVAluATION OF THEMEDA TRIANDRA AS AN INDICATOR FOR MONITORING THE EFFECTS OF GRAZING AND FIRE IN THE BONTEBOK NATIONAL PARK
}

\begin{abstract}
Authors:
Peter Novellie ${ }^{1}$

Tineke Kraaij ${ }^{2}$
\end{abstract}

\section{Affiliations:}

${ }^{1}$ South African National

Parks, Conservation

Services, Pretoria,

South Africa

${ }^{2}$ South African National Parks, Scientific Services, Sedgefield, South Africa

\section{Correspondence to:}

Peter Novellie

email:

petern@sanparks.org

Postal address:

SANParks, PO Box 787,

Pretoria 0001, South Africa

Keywords:

defoliation; fynbos; grass cover; heterogeneity; renosterveld; threshold of potential concern

\section{Dates:}

Received: 29 Oct. 2009

Accepted: 25 Mar. 2010

Published: 13 July 2010

How to cite this article: Novellie, P. \& Kraaij, T., 2010, 'Evaluation of Themeda triandra as an indicator for monitoring the effects of grazing and fire in the Bontebok National Park', Koedoe 52(1), Art. \#977, 5 pages. DOI: $10.4102 /$ koedoe. v52i1.977

This article is available at:

http://www.koedoe.co.za

(C) 2010. The Authors. Licensee: OpenJournals Publishing. This work is licensed under the Creative Commons Attribution License.

\begin{abstract}
Up until 2004, the burning regime applied in the Bontebok National Park was aimed at maintaining grazing conditions suitable for bontebok (Damaliscus pygargus pygargus). It was, however, not suitable for maintaining plant species diversity, an increasingly urgent conservation priority for the park. Accordingly, the burning regime was changed in 2004 to increase the interval between fires. A possible unintended outcome of the new burning regime is the spread of grazing lawns which is likely to be deleterious for maintaining the diversity of rare plants. Red grass, Themeda triandra, a species often locally abundant in areas preferred by bontebok, is potentially a good indicator of the anticipated change because, although it persists with moderate grazing, it is sensitive to localised intense grazing and will decrease on grazing lawns. To gauge the potential of this indicator, the canopy spread cover, degree of defoliation and inflorescence production of $T$. triandra was determined at 13 permanently marked sites in November 2005. The results are compared with a survey conducted 20 years previously (October-November 1984 and October-November 1985) using similar methodology. The results suggest that $T$. triandra remained abundant over the previous 20 years' application of the prior burning regime. In 1984-1985, defoliation of T. triandra was high within 1 year after a fire but declined quickly thereafter. In 2005, the tendency for the defoliation level to decline with increasing time after a fire was still apparent, but it was much less marked than in the previous survey period. A likely cause of this was the fact that Cape mountain zebra (Equus zebra zebra) and red hartebeest (Alcelaphus buselaphus caama) were present in 2005 but absent in 1984-1985 and these taller-grass grazers would have contributed to the use of the older veld. Provided it is interpreted together with other monitoring programmes, the use of $T$. triandra cover and defoliation intensity appears promising as an efficient indicator of some of the potentially deleterious outcomes of the interactions between herbivory and the new burning regime.
\end{abstract}

Conservation implications: The conservation objectives of maintaining (1) large mammal herbivory as an ecological process and (2) plant species diversity may be difficult to reconcile with each other in the highly fragmented renosterveld and lowland fynbos ecosystems. This paper explores a rapid approach to monitoring impacts of bontebok and other grazing ungulates.

\section{INTRODUCTION}

The Bontebok National Park (BNP) was established at its current location near the town of Swellendam in the Western Cape Province in 1960 to save the bontebok (Damaliscus pygargus pygargus) from extinction. In this the park was successful, allowing the bontebok to increase in numbers and strengthening its conservation status. In contrast to the successful regeneration of the bontebok, the vegetation of the BNP, which comprises renosterveld and lowland fynbos (Kraaij in press), has become a conservation priority due to near-complete habitat destruction outside the park (Von Hase et al. 2003).

In 2004, in response to the increasing need to prioritise vegetation conservation, a new fire regime was introduced (Kraaij 2010). The interval between fires was extended to not less than 8 years for renosterveld vegetation and to not less than 16 years for fynbos. Under the previous fire regime, the average fire return period was 5.8 years for renosterveld and 8 years for fynbos (Kraaij 2010). The new fire regime for fynbos in the BNP follows general practice (Kruger \& Bigalke 1984; Van Wilgen et al. 1992; Van Wilgen et al. in press), in that it is based on the requirements of the serotinous plants in the vegetation (these are slowmaturing plants that depend on canopy-stored seeds to regenerate after fire).

Under the previous fire regime, a substantial area of newly burnt veld was available every year and, because fire was the main driver of spatial variation in grazing pressure, the burning regime was successful in promoting a rotation of grazing pressure (Kraaij \& Novellie 2010). The new regime prescribes the biennial burning of an area that is comparable in size to that which was previously burnt annually. In effect, newly burnt veld is now available only every second year.

Evidence from savannahs (Archibald et al. 2005; Archibald 2008) suggests that the new fire regime may have the unintended outcome of facilitating the spread of grazing lawns in the park. 'Grazing lawns' is a term coined by McNaughton (1984) to mean 'areas created and maintained by heavy grazing with unique assemblages of grazing adapted grass species'. These areas are important determinants of spatial heterogeneity in African grassland ecosystems (Archibald et al. 2005; Cromsigt \& Olff 2008). Bontebok, like the conspecific blesbok (Damaliscus pygargus phillipsi), are short-grass grazers and tend to repeatedly graze localised patches (Du Plessis 1972; Grobler 1983; Kraaij \& Novellie 2010; Novellie 1987; Novellie 1990). The territorial behaviour of both bontebok and blesbok results in localised accumulations of dung and urine (David 1973), which promote the formation of stoloniferous, lawn-forming grasses such as couch grass (Cynodon dactylon). Because of the attractiveness of newly burnt veld to grazers, fires play a role in dispersing grazing pressure, thereby preventing the formation of grazing lawns (Archibald $e t$ al. 2005; Archibald 2008). Thus, the reduced fire frequency in BNP may lead to increased patch-selective grazing and the spread of grazing lawns. 
Grazing lawns are a widespread natural phenomenon in grassland ecosystems (Archibald et al. 2005; McNaughton 1984; Stock et al. 2010) and play an important role in creating and maintaining spatial heterogeneity and habitat diversity (Cromsigt \& Olff 2008; Novellie 1990; Pickett et al. 2003). Grazing lawns may be beneficial in the BNP only if their area remains within stable limits, for then grazing would be concentrated in relatively confined areas, leaving the rest of the park ungrazed or grazed at a low intensity. However, if the total area of grazing lawns were to undergo progressive expansion it would be deleterious for the threatened vegetation types in the park. Certain species of Red Data plants in the BNP (Kraaij in press; Raimondo et al. 2009) (Aspalathus burchelliana, A. grobleri, A incompta, A. lebeckioides, Haworthia heidelbergensis, H. marginata $H$. mirabilis, Stoebe rugulosa) are found in the general vicinity of intensively grazed areas, but do not occur on, or near, grazing lawns (Kraaij pers. obs.). The spread of grazing lawns in the BNP may threaten species such as these, as well as plant species diversity in general, thereby constituting a threshold of potential concern (sensu Biggs \& Rogers 2003).

A monitoring system is required that is capable of reflecting a sustained increase in the area of grazing lawns. Under ideal circumstances, this would justify an intensive, multi-component monitoring system. However, personnel and resources are too limited for intensive monitoring and, as such, there is a need to develop a simple indicator that could be sampled rapidly to check for the anticipated vegetation changes. In this paper we examine the potential of using a rapid cover assessment of one important grass species, Red grass, Themeda triandra, as an indicator. The reasons for selecting this species are as follows:

- Firstly, this grass species grows abundantly in those parts of the BNP favoured by bontebok and thus tends to be subjected to heavy grazing (Novellie 1987).

- Secondly, grazing lawn formation is characterised by the replacement of bunch grasses, such as $T$. triandra, with grazing-tolerant stoloniferous grasses (Archibald et al. 2005; Cromsigt \& Olff 2008; Novellie 1990).

- Thirdly, T. triandra is not easily confused with other grasses in the BNP; observers can quickly learn to recognise it even in a vegetative state.

There is reason to expect that T. triandra may decline not only as a result of localised intense grazing, but also as a result of very low grazing pressure in association with infrequent burning. This species is known to thrive when it is frequently burnt, but like many grass species, it declines with prolonged absence of fire and grazing (Raitt 2005; Tainton 1981). This may occur particularly on the management units that are only burn at 16-year intervals. Therefore, we also examine the degree of defoliation and inflorescence production of $T$. triandra, on the grounds that these additional observations may be helpful in interpreting the driving factors behind observed trends in cover.

\section{STUDY AREA}

The 3475 ha BNP is situated $8 \mathrm{~km}$ from the town of Swellendam (Figure 1) in the Western Cape Province ( $\left.34^{\circ} 02^{\prime} \mathrm{S}, 20^{\circ} 25^{\prime} \mathrm{E}\right)$. The annual rainfall is $511 \mathrm{~mm}$, of which $59 \%$ falls in winter. Rebelo et al. (2006) classified the vegetation of the BNP as Swellendam Silcrete Fynbos, considering it a poorly known vegetation unit that exhibits floristic features of both fynbos and renosterveld, with very high plant species richness (Kraaij in press).

\section{METHOD}

The percentage of canopy spread cover and level of defoliation were determined using the procedure of Novellie (1987). However, to achieve a quick and simple indicator-based method, the procedure was adapted as follows:

- Instead of locating the points at 1-m intervals along a tape measure (Novellie 1987), the points were located using the step-point method of Evans and Love (1957), as modified by Mentis (1981), with the points being taken at every second step.

- Only 'hits' on T. triandra were recorded, other plant species were ignored.

In both this study and that of Novellie (1987), a 'hit' was recorded if the point fell within the perimeter of the canopy of the grass tuft. In both studies, the canopy spread cover was calculated as a ratio of hits to total points examined and was expressed as a percentage.

The assessment of defoliation of individual tufts was also simplified by distinguishing only three defoliation classes, instead of the five classes of Novellie (1987). The three classes were, (1) no defoliation, (2) less than $50 \%$ of shoots severed and (3) more than $50 \%$ of shoots severed.

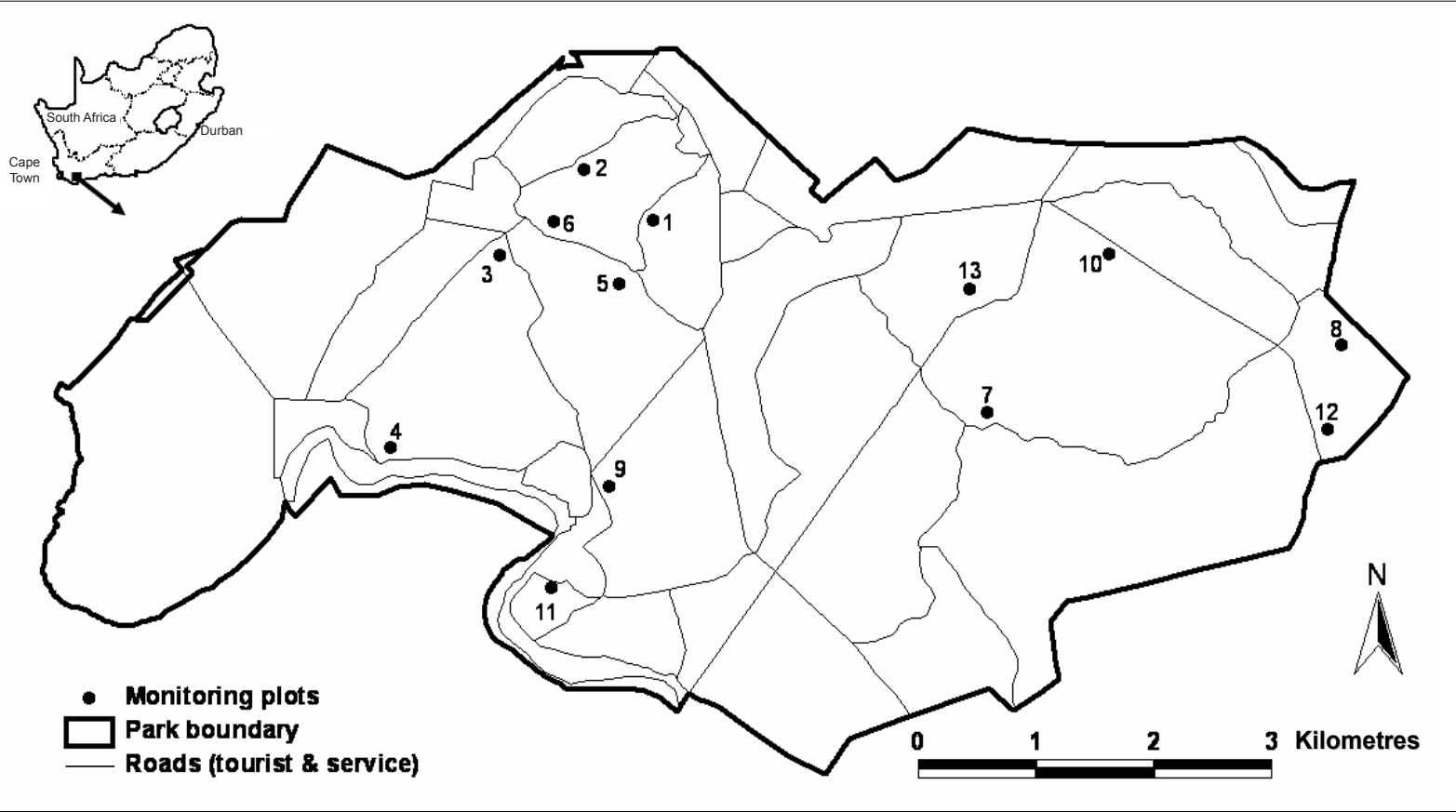

FIGURE 1

The Bontebok National Park showing the locations of the monitoring plots 
Midpoint values of each class were used to calculate an index of defoliation (i.e. the mean percentage defoliation), as described by Novellie (1987). The presence or absence of inflorescences was noted in order to assess the relationships between grazing, burning and seed production.

Novellie (1987) applied this procedure in eight plots, chosen in patches of renosterveld vegetation that were particularly favoured by bontebok. The corners of each plot were marked with steel fencing standards and its approximate location was indicated on a map of the park. Novellie's surveys were conducted during October and November in both 1984 and 1985.

In this study, an attempt was made to relocate these plots, but the markers could be found for only four of them (Plots 2, 4, 5 and 6 of Novellie 1987). The location of an additional plot (Plot 9) could be derived with reasonable certainty from the map. In November 2005, step-point surveys for T. triandra cover were conducted in the five relocated plots and in an additional eight plots that were located in patches of renosterveld favoured by bontebok. A GPS reading was taken to mark the corner of each plot. It was necessary to obtain a sufficient sample of hits to determine the degree of defoliation and inflorescence production. Judging subjectively that 30 would be enough, the survey within each plot was continued until at least this number of hits on T. triandra had been obtained. The number of steppoints necessary to achieve this varied between 100 and 430 (Table 1).
The date of the last burning was known for all plots surveyed by Novellie (1987) and the present study, so the results could be examined in relation to 'veld age' (time since last fire).

\section{RESULTS}

For the 13 plots surveyed in November 2005, the duration of sampling by a single observer of each plot varied from $13 \mathrm{~min}$ to $28 \mathrm{~min}$ (Table 1); the time taken for all 13 plots was just short of $4.5 \mathrm{~h}$. Considering the time needed to travel from one plot to the next, it seems reasonable to conclude that the sampling of all plots could be completed by a single observer within two days' field work.

The mean percentage defoliation of $T$. triandra declined with increasing time since the last fire (Table 1 and Figure 2). This would be expected from the fact that all large herbivore species in the park tend to concentrate on areas up to 5 years after burning, whereas areas that have not been burnt for 5 years or longer are generally avoided (Kraaij \& Novellie 2010). A small proportion of $T$. triandra tufts bore inflorescences within the first 2 years after burning, but thereafter inflorescence production increased (Figure 3).

We compared the cover and mean percentage defoliation of this study with that of Novellie (1987) for those plots that could be

TABLE 1

Canopy spread cover, defoliation index (mean percentage defoliation) and presence of inflorescences in Themeda triandra, as determined from step-point surveys conducted in 13 monitoring plots in renosterveld, Bontebok National Park

\begin{tabular}{|c|c|c|c|c|c|c|c|c|c|c|c|c|c|}
\hline & Plot 1 & Plot 2 & Plot 3 & Plot 4 & Plot 5 & Plot 6 & Plot 7 & Plot 8 & Plot 9 & Plot 10 & Plot 11 & Plot 12 & Plot 13 \\
\hline Sampling duration (minutes) & 28 & 17 & 18 & 15 & 25 & 13 & 22 & 18 & 25 & 22 & 18 & 18 & 25 \\
\hline Total number of points & 270 & 140 & 140 & 100 & 270 & 180 & 430 & 350 & 120 & 200 & 330 & 160 & 260 \\
\hline Canopy spread cover (\%) & 21 & 46 & 44 & 55 & 19 & 33 & 9 & 10 & 43 & 29 & 6 & 38 & 22 \\
\hline Mean defoliation (\%) & 43 & 43 & 63 & 41 & 67 & 65 & 29 & 45 & 34 & 19 & 24 & 58 & 11 \\
\hline Percentage with inflorescences & 5 & 39 & 8 & 40 & 12 & 12 & 74 & 47 & 35 & 71 & 90 & 17 & 33 \\
\hline Veld age (years since fire) & 1.8 & 1.8 & 1.8 & 8.6 & 1.8 & 1.8 & 6.6 & 4.5 & 13.5 & 6.6 & 10.7 & 4.5 & 3.5 \\
\hline
\end{tabular}

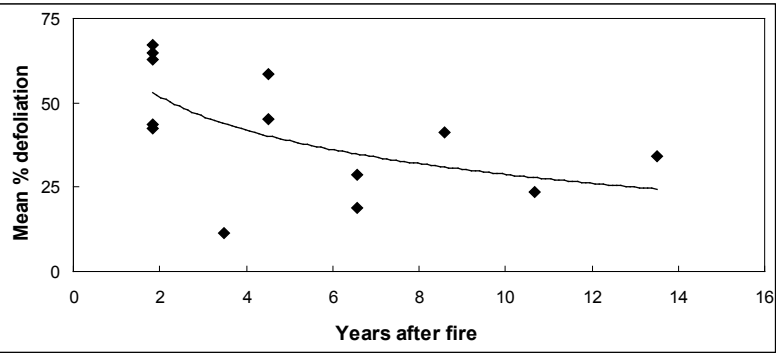

FIGURE 2

Mean percentage defoliation of Themeda triandra in relation to years after fire (2005 data)

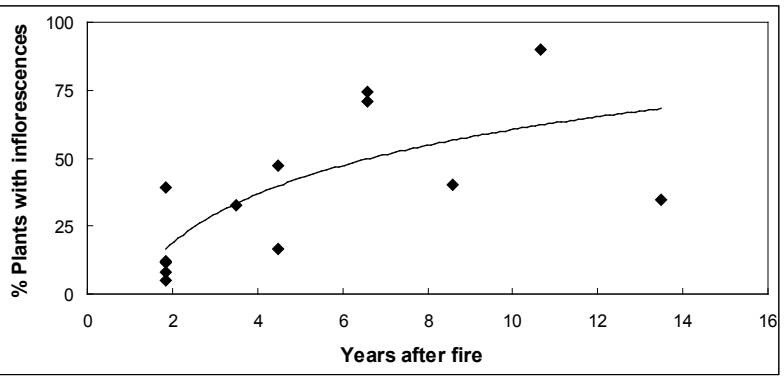

FIGURE 3

Percentage of Themeda triandra tufts bearing inflorescences in relation to years after fire (2005 data)
TABLE 2

Canopy spread cover and mean percentage defoliation of Themeda triandra compared between this study (the year 2005) and that of Novellie (1987) (the years 1984 and 1985) for those of Novellie's plots which could be relocated in this study Relocated plots

\begin{tabular}{lccc}
\cline { 2 - 4 } & $\mathbf{1 9 8 4}$ & $\mathbf{1 9 8 5}$ & $\mathbf{2 0 0 5}$ \\
\hline Plot 2 & & & \\
Canopy spread cover (\%) & 6.0 & 16.0 & 46.0 \\
Mean defoliation (\%) & 16.0 & 1.0 & 43.0 \\
Veld age (years since fire) & 1.5 & 2.6 & 1.8
\end{tabular}

Plot 4

Canopy spread cover (\%)

Mean defoliation (\%)

Veld age (years since fire)

$\begin{array}{lll}1.0 & 1.0 \quad 55.0\end{array}$

Plot 5

Canopy spread cover (\%)

Mean defoliation (\%)

Veld age (years since fire)

50.0

41.0

$\begin{array}{lll}0.5 & 1.6 \quad 8.6\end{array}$

Plot 6

Canopy spread cover (\%)

Mean defoliation (\%)

Veld age (years since fire)

$2.0 \quad 13.0$

67.0

19.0

$19.0-67.0$

$\begin{array}{lll}0.5 & 1.6 & 1.8\end{array}$

Plot 9

Canopy spread cover (\%)

Mean defoliation (\%)

Veld age (years since fire)

Rainfall one year before survey $(\mathrm{mm})$

Annual rainfall $(\mathrm{mm})$ averaged over two years before survey

Annual rainfall $(\mathrm{mm})$ averaged over three years before survey 
relocated (Table 2). The cover values of T. triandra in 2005 were generally higher than those of 1984-1985. Rainfall variability can have a major influence on grass cover (Fuhlendorf et al. 2001); hence it is possible that the high cover in 2005 was due to the higher level of rainfall that had preceded these surveys (Table 2). For the comparison of mean percentages of defoliation (Table 2 ), the raw data of Novellie (1987) were grouped into three defoliation classes to match the data collected in 2005. Novellie (1987) reported that defoliation of all grass species was very high within 1 year after a fire but declined sharply thereafter. Comparison of the mean defoliation between 1984 and 1985 (Table 2) shows how this occurs for T. triandra. In contrast, the 2005 surveys did not show the same sharp decline in use with veld age; the mean defoliation of $T$. triandra was relatively high even several years after fire (Table 2, Figure 1). Cape mountain zebra (Equus zebra zebra) and red hartebeest (Alcelaphus buselaphus caama) were relatively abundant in the park in 2005 whereas they were absent in 1984-1985. Kraaij and Novellie (2010) found that zebra and hartebeest do not concentrate on recently burnt veld to the same extent as the bontebok, but more readily use older veld. The presence of zebra and hartebeest in 2005 may therefore explain the higher use of $T$. triandra on the older veld. In drawing conclusions from Table 2 it needs to be recognised that, owing to missing markers, the 2005 surveys could not be done within exactly the same areas as those of 1984 and 1985. Furthermore, as noted above, the methods used to locate the points differed between this study and Novellie (1987). There may also have been differences between observers; Novellie was the sole observer in 1984 and 1985, whereas Kraaij conducted all observations in 2005. The extent to which these factors may have influenced results is unknown. Nevertheless, the results show that there was no significant decline in T. triandra over the 20 years between 1985 and 2005 .

\section{DISCUSSION}

Themeda triandra was one of the dominant forage species during the 1980s, when bontebok was the only grazer in the BNP (Novellie 1987) and it was still highly favoured by grazers in 2005. The results suggest that $T$. triandra persisted well in the BNP for 20 years under the application of the previous burning regime. This may be expected, especially in view of the fact that it is favoured by frequent burning and moderate grazing (the previous regime evidently having rotated grazing pressure, thereby reducing patch selectivity). Monitoring of T. triandra cover, defoliation and inflorescence production therefore seems promising as an indicator of at least some of the anticipated outcomes of the revised fire management programme. In areas that are subjected to prolonged heavy grazing the expected trend may be:

- a number of successive years with high mean defoliation (in excess of $50 \%$ ), decreasing little or not at all with time since the last fire

- limited inflorescence production, not increasing with time since fire

- eventual decline in cover of T. triandra at the expense of lawn-forming grasses such as Cynodon dactylon.

At these sites we recommend examining the cover of Cynodon dactylon during the step-point surveys, in addition to that of $T$. triandra, as the former grass will be a good indicator of grazing lawn formation.

In areas that are infrequently grazed and burnt the trend may consist of a number of successive years with low mean defoliation of T. triandra tufts, which show an accumulation of old leaves and inflorescences, as well as an eventual decline in $T$. Triandra cover at the expense of woody plants.

By itself, T. triandra would be an insufficient indicator for management. At most it would provide an early warning of trends that should be examined in more detail. A vital requirement of the monitoring programme is to consider the use of space by the large herbivores in relation to fire. This constitutes an existing herbivore census programme, which has continued in the BNP, although with gaps, over many years (Kraaij \& Novellie 2010). The following five additional monitoring programmes are important:

1. abundance of Red Data plant species (mostly woody shrubs; Kraaij in press)

2. the extent and dynamics of grazing lawn formation

3. performance of the large herbivore populations, for example, the reproduction rates in bontebok (Novellie 1986)

4. weather records, especially rainfall

5. incidence of planned and unplanned fires (Kraaij 2010; Van Wilgen et al. in press).

Programme 1 was introduced in 2003 and is ongoing in partnership with the Threatened Species Programme of the South African National Biodiversity Institute. Programme 2 is currently not implemented, but is considered a priority and Programmes 3-5 are currently being kept in operation.

\section{CONCLUSION}

In terms of determining the threshold of potential concern (Biggs \& Rogers 2003), the key concern would be to establish whether the area of grazing lawns expands progressively, or whether it remains within acceptable limits from the point of view of maintaining plant species diversity. Further work is needed to determine an appropriate regime for sampling the indicator that would be useful for detecting where this threshold has potentially been crossed. An option would be to extend the sample of 13 plots surveyed in this study to represent all of the management units ('burning blocks') in the BNP, so that trends in each unit could be examined in relation to the grazing and fire history of each unit. However, given the high variability of the indicator when compared between individual monitoring plots of the same veld age (Tables 1 and 2), the sampling intensity necessary to achieve representation of all units may be prohibitively high. An alternative may be to determine the areas of highest and lowest grazing intensities and to sample the indicator over a gradient from high to low grazing intensity. It would also be worth investigating the potential use of satellite imagery to determine the area of lawn and bunch grasses (Archibald et al. 2005).

\section{ACKNOWLEDGEMENTS}

Editor: Llewellyn C. Foxcroft

\section{REFERENCES}

Archibald, S., 2008, 'African grazing lawns - How fire, rainfall, and grazer numbers interact to affect grass community states', Journal of Wildlife Management 72(2), 492-501.

Archibald, S., Bond, W.J., Stock, W.D. \& Fairbanks, D.H.K., 2005, 'Shaping the landscape: Fire-grazer interactions in an African savanna', Ecological Applications 15, 96-109.

Biggs, H.C. \& Rogers, K.H., 2003, 'An adaptive system to link science, monitoring, and management in practice', in J.T. du Toit, K.H. Rogers \& H.C. Biggs (eds.), The Kruger experience: Ecology and management of savanna heterogeneity, pp. 59-80, Island Press, Washington DC.

Cromsigt, P.G.M. \& Olff H., 2008, ‘Dynamics of grazing lawn formation: An experimental test of the role of scaledependent processes', Oikos 117, 1444-1452.

David, J.H.M., 1973, 'The behaviour of the bontebok, Damaliscus dorcas dorcas, (Pallas 1766), with special reference to territorial behaviour', Zeitschrift fur Tierpsychologie 33, 38-107.

Du Plessis, S.S., 1972, 'Ecology of blesbok with special reference to productivity', Wildlife Monographs 30, 6-70.

Evans, R.A. \& Love, R.M., 1957, 'The step-point method of sampling - A practical tool in range research', Journal of Range Management 10, 208-212. 
Fuhlendorf, S.D., Briske, D.D. \& Smeins, F.E., 2001, ‘Herbaceous vegetation change in rangeland environments: The relative contribution of grazing and climatic variability', Applied Vegetation Science 4, 177-188.

Grobler, J.H., 1983, 'Feeding habits of the Cape mountain zebra', Koedoe 26, 159-168.

Kraaij, T., 2010, 'Changing the fire management regime in the renosterveld and lowland fynbos of the Bontebok National Park', South African Journal of Botany, doi:10.1016/j. sajb.2010.04.008.

Kraaij, T., in press, 'Bontebok National Park: Hotspot of plant diversity within the Cape Floral Kingdom', South African Journal of Botany.

Kraaij, T. \& Novellie, P.A., 2010, 'Habitat selection by large herbivores in relation to fire at the Bontebok National Park (1974-2009): The effects of management changes', African Journal of Range and Forage Science 27(1), 21-27.

Kruger, F.J. \& Bigalke, R.C., 1984, 'Fire in fynbos' in P.V. Booysen \& N.M. Tainton (eds.), Ecological effects of fire in South African ecosystems (Ecological Studies 48), pp. 67-114, Springer-Verlag, Berlin.

McNaughton, S.J., 1984, 'Grazing lawns: Animals in herds, plant form, and coevolution', The American Naturalist 124(6), 863-886.

Mentis, M.T., 1981, 'Evaluation of the wheel-point and steppoint methods of veld condition assessment', Proceedings of the Grassland Society of southern Africa 16, 89-94.

Novellie, P., 1986, 'Relationships between rainfall, population density and the size of the bontebok lamb crop in the Bontebok National Park', South African Journal of Wildife Research 16, 39-46.

Novellie, P., 1987, 'Interrelationships between fire, grazing and grass cover at the Bontebok National Park', Koedoe 30, 1-17.

Novellie, P.A., 1990, 'Habitat use by indigenous grazing ungulates in relation to sward structure and veld condition', Journal of the Grassland Society of southern Africa 7, 16-23.
Pickett, S.T.A., Cadenasso, M.L. \& Benning, T.L., 2003, 'Biotic and abiotic variability as key determinants of savanna heterogeneity at multiple spatiotemporal scales', in J.T. du Toit, K.H. Rogers \& H.C. Biggs (eds.), The Kruger experience, ecology and management of savanna heterogeneity, pp. 22-40, Island Press, Washington DC.

Raimondo, D., Von Staden, L., Foden, W., Victor, J.E., Helme, N.A., Turner, R.C. et al. (eds.), 2009, Red list of South African plants (Strelitzia 25), South African National Biodiversity Institute, Pretoria.

Raitt, G., 2005, 'The effect of management on Themeda renosterveld grasslands in the Groot Vaders Bosch Conservancy', MSc thesis, Conservation Ecology Department, University of Stellenbosch

Rebelo, A.G., Boucher, C., Helme, N., Mucina, L. \& Rutherford, M.C., 2006, 'Fynbos Biome', in L. Mucina \& M.C. Rutherford (eds.), The vegetation of South Africa, Lesotho and Swaziland (Strelitzia 19), pp. 158-159, South African National Biodiversity Institute, Pretoria.

Stock, W.D., Bond, W.J. \& Van de Vijver, C.A.D.M., 2010, 'Herbivore and nutrient control of lawn and bunch grass distributions in a southern African savanna', Plant Ecology 206(1), 15-27.

Tainton, N.M., 1981, 'The effect of mowing, burning and grazing on species composition of pastures', in N.M. Tainton (ed.), Veld and pasture management in South Africa, pp. 265-268, Shuter and Shooter, Pietermaritzburg.

Van Wilgen, B.W., Bond, W.J. \& Richardson, D.M., 1992, 'Ecosystem management', in R.M. Cowling (ed.), The ecology of fynbos. Nutrients, fire and diversity, pp. 345-371, Oxford University Press, Oxford.

Van Wilgen, B.W., Govender, N., Forsyth, G.G. \& Kraaij, T., in press, "The adaptive management of fire regimes for the conservation of biodiversity: Examples from South African National Parks', Koedoe.

Von Hase, A., Rouget, M., Maze, K. \& Helme, N., 2003, A fine-scale conservation plan for Cape Lowlands Renosterveld, technical report No. CCU2/03, Cape Conservation Unit, Botanical Society of South Africa, Cape Town. 